\title{
Transport and Metabolism of Glucose, Insulin Sensitivity and Lipolysis of Epididymal Adipose Tissue of Alloxan-Diabetic Rats after Prolonged Incubation in vitro*
}

\author{
U.A. Meyer, V. Sturzenegger and E.R. Froesch
}

Metabolic Unit, Department of Medicine, University of Zürich, Zürich, Switzerland

Received July 10, 1967

Summary. The metabolism of diabetic adipose tissue was studied after prolonged prëncubation in vitro $(16 \mathrm{~h})$ in a medium containing albumin and glucose with and without insulin. The initially decreased glucose uptake and metabolism of diabetic adipose tissue rose to normal levels during incubation. This increase was subject to inhibition by phlorizin, indicating that facilitated glucose diffusion was responsible. The tissue remained insulinsensitive during prolonged incubation. However, insulin sensitivity did not increase in the same way as basal glucose uptake. - Glycerol release and incorporation of glucose-U.14C into glyceride-glycerol increased during incubation, and both were inhibited to some extent by insulin. Fatty acid synthesis from glucose- ${ }^{-14} \mathrm{C}$ increased during incubation but did not reach normal values. - Unlike tissues of fed rats, phosphorylation of glucose rather than transport became the rate-limiting step in glucose metabolism after prolonged incubation in vitro. Cycloheximide, but not actinomycin $\mathrm{D}$, inhibited the preîneubation effect.

Transport et métabolisme du glucose, sensibilité à l'insuline et lipolyse du tissu adipeux épididymaire de rats rendus diabétiques par l'alloxane après incubation prolongée in vitro

Résumé. Le métabolisme glucidique du tissu adipeux diabétique après jneubation pendant $16 \mathrm{~h}$ dans un tampon contenant du glucose et de l'albumine, avec ot sans insuline a été examiné. Lo métabolisme glucidique d' abord diminué s'élevait à des taux normaux lors de l'incubation. Puisque la phlorizine supprimait cet effet stimulateur de l'incubation la diffusion facilitée du glucose semble être en cause. La sensibilité à l'insuline était maintenue pendant l'incubation, mais elle n'augmentait pas. - La libération de glycérol ainsi que l'incorporation du glucose-U-14 C dans la fraction glycéride-glycérol augmentaient au cours de l'incubation et, alors, étaient inhibées par l'insuline. La synthèse des acides gras à partir du glucose-U-14 $\mathrm{C}$ augmentait également mais n'atteignait pas des valeurs normales. - Tandis que le transport du glucose limite le métabolisme du glucose dans le tissu adipeux normal, la phosphorylation devenait le facteur limitant après l'ineubation prolongée. Un agent inhibiteur de la synthèse des protéines, la cycloheximide, inhibait la stimulation du métabolisme du glucose par l'in. cubation même, tandis que l'actinomycine D était sans effet.

Glucosetransport und -stoffwechsel, Insulinempfindlichkeit und Lipolyse des epididymalen F eltgervebes alloxandiabetischer Ratten nach längerer Inkubation in vitro

Zusammenfassung. Diabetisches Fettgewebe wurde während 16 Std in einem Puffer mit Albumin und Glucose mit und ohne Insulin inkubiert, und die resultierenden Stoffwechselveränderungen mit Glucose-U. ${ }^{14} \mathrm{C}$ während einer zweiten Inkubation gemessen. Der anfänglich verminderte Glucosestoffwochsel des diabetischen Gewebes normalisierte sich im Verlaufe der Vorinkubation. Da Phlorizin diesen Vorinkubationseffekt auf die Glucoseaufnahme hernmte, darf eine Steigerung der Aktivität des mobilen Carriers dafür verantwortlich gemacht werden. Die Insulinempfindlichkeit des Gewebes blieb während der verlängerten Inkubation erhalten, nahm aber nicht parallel zur basalen Glucoseaufnahme zu. - Die Glycerinabgabe und der Einbau von Glucose-U. ${ }^{14} \mathrm{C}$ in die Glycerid-Glycerol-Fraktion nahm während der Inkubation zu und beide wurden durch Insulin zum Teil gehemmt. Die Fettsäuresynthese aus Glucose-U-14C wurde gesteigert, normalisierte sich aber nicht vollständig. - Im Gegensatz zu normalem Gewebe wurde an Stelle des Transportes die Phosphorylierung der Glucose zum geschwindigkeitsbestimmenden Faktor des Glucosestoff. wechsels. Cycloheximid verminderte den Vorinkubationseffekt auf den. Glucosestoffwechsel, während Actinomyein D ohne Wirkung war.

Key-words : Adipose tissue of diabetic rats, prolonged incubation in vitro, glucose transport and metabolism, fructose metabolism, insulin sensitivity, lipolysis.

\section{Introduction}

The decreased glucose metabolism of adipose tissue of fasted rats can be raised by prolonged incubation of the tissue in vitro $[31,21,10]$.

In a previous study $[37,38]$ we have shown that the diminished glucose uptake of adipose tissue of alloxan-diabetic rats is stimulated to normal levels within 8 to $16 \mathrm{~h}$ during incubation in vitro in the absence of insulin.

* Supported by grants from the United States Public Health Service (A 5,387) and from the Sehweizerischer Nationalfonds $(\mathbf{3}, 854)$.
This report deals with the mechanisms responsible for the partial normalization of the insulin-independent glucose metabolism during incubation in vitro. Glucose and fructose transport, hexose-14 $\mathrm{C}$ metabolism and adipose tissue lipolysis as influenced by prolonged incubation and by insulin were studied.

Evidence is presented that the increased insulinindependent glucose penetration during prolonged incubation proceeds by way of facilitated diffusion and that phosphorylation rather than transport becomes rate-limiting in overall glucose metabolism. 


\section{Materials and Methods}

Glycerol was determined enzymatically using the reagents of Biochimica (Boehringer, Mannheim, Germany). Free fatty acids of the medium were extracted and titrated according to GORDON [27]. Uniformly labelled glucose- ${ }^{14} \mathrm{C}$ and fructose $-{ }^{14} \mathrm{C}$ were purchased from the Radiochemical Centre, Amersham, Buckinghamshire, England. They were chromatographically pure.

Total lipids were extracted according to FoLcI et al. [13]. The extract was dried, taken up and washed with isooctane: glacial acetic acid $(1: 1)$. The fatty acids were obtained by hydrolysis of the total lipids in alcoholic KOH. Incorporation of glucose ${ }^{14} \mathrm{C}$ into glyceride-glycerol was calculated from the difference between the counts in the total lipids and those in the hydrolyzed fatty acids. The dried fat-free tissue was digested in $30 \% \mathrm{KOH}$ and the glycogen was precipitated with cold ethanol $(95 \%)$ and twice reprecipitated before counting. The glycogen content of the tissues was measured by the determination of glucose after hydrolysis of the planchetted glycogen in $1 \mathrm{~N} \mathrm{HCl}$. The term "glucose metabolism" often used in the text, denotes the sum of the incorporation of glucase- $\mathrm{U}^{14} \mathrm{C}$ into $\mathrm{CO}_{2}$ and total lipids. Incorporation into these two metabolites accounts for $70 \%$ or more of the actual hexose uptake [20,18].

Phlorizin dihydrate was purchased from Fluka $A G$, Buchs, Switzerland; actinomycin D and cycloheximide from Merck, Sharp and Dohme, West Point, Pa. and from Calbiochem, Los Angeles, Calif., respectively. Crystalline pork insulin with an activity of 23.9 units/ mg was a gift of Dr. J. Schlichtkrull, Novo Terapeutisk Laboratorium, Copenhagen.

\section{Experimental procedure}

Alloxan diabetes: Alloxan in a dose of $45 \mathrm{mg} / \mathrm{kg}$ was injected into the tail vein of pure-bred Osborne-Mendel rats weighing $140-160 \mathrm{~g}$ after a 24 -h fast. Thereafter the rats had free access to food, and were killed in diabetic ketosis $96 \mathrm{~h}$ after the alloxan-injection. Occasionally, $10 \mathrm{ml}$ of Ringer solution containing $0.3 \mathrm{meq}$ of potassium was administered subcutaneously on the third and fourth day after alloxan-injection. Blood sugar values above $500 \mathrm{mg}$ per $100 \mathrm{ml}$ and a weight loss of $10 \mathrm{~g}$ or more served as criteria of diabetes. A considerable percentage of rats was lost before the start of the experiment.

Incubation technique: The details of the incubation technique have been described elsewhere [37]. The medium used throughout was a sterile bicarbonate buffer solution (EARLE) [7] containing human albumin ${ }^{1}$

1 Human albumin, fraction V, Lot No. 65/08-10 was purchased from the Blutspendedienst, Swiss Red Cross, Bern. It had neither insulin-like nor insulin-inhibitory activity on the fat pad in concentrations up to $6 \mathrm{~g}$ per $100 \mathrm{ml}$. in a concentration of $1.5 \mathrm{~g}$ per $100 \mathrm{ml}$. Since pooling of adipose tissue as normally practiced in our laboratory [17] was unfavourable for medium changes and was harmful for the tissue, the entire pads were preincubated and transferred into fresh buffer solution after $8 \mathrm{~h}$. For the final incubation the pads were rinsed, cut into small pieces and pooled. The results of this final incubation were compared with those obtained with pools of adipose tissue which had not been preïncubated (initial incubation).

Adipose tissue takes up considerable amounts of water during prolonged incubations $[37,25,4]$. Therefore, the results of the final incubation refer to the initial weight of the tissue. All incubations were carried out in $25 \mathrm{ml}$ polyethylene flasks (Packard) in a Dub. noff metabolic shaker at $37^{\circ} \mathrm{C}$ under continuous gassing with a mixture of $95 \% \mathrm{O}_{2}-5 \% \mathrm{CO}_{2}$.

\section{Results}

a) Effect of increasing glucose concentrations on fructose- $U-{ }^{14} C$ and glucose- $U-{ }^{14} C$ metabolism after prolonged incubation. In the range between 10 and $200 \mathrm{mg}$ of glucose per $100 \mathrm{ml}$ the oxidation of glucose to $\mathrm{CO}_{2}$ and its incorporation into total lipids increased continuously. In a representative experiment in which the concentrations of glucose were 50, 200 and $800 \mathrm{mg}$ per $100 \mathrm{ml}$ respectively, the sums of $u$ moles of glucose oxidized to $\mathrm{CO}_{2}$ and incorporated into total lipids per $\mathrm{g}$ per $h$ were: $3.50 \pm 0.30(6.46 \pm 0.22), 6.29 \pm 0.36(7.74$ $\pm 0.61)$ and $7.72 \pm 0.19(7.91 \pm 0.20)$ respectively. These values are means of duplicate determinations. The figures in parentheses give the corresponding values in the presence of $1000 \mu \mathrm{U}$ of insulin per ml. Glucose metabolism was nearly maximal at a glucose concentration of $50 \mathrm{mg}$ per $100 \mathrm{ml}$ in the presence of insulin. At a glucose concentration of $800 \mathrm{mg}$ per 100 $\mathrm{ml}$, glucose metabolism was no longer stimulated by insulin.

Fig. 1 shows the effect of increasing glucose concentrations on fructose- $\mathrm{U}_{-}{ }^{14} \mathrm{C}$ metabolism by adipose tissue of diabetic rats after incubation for $16 \mathrm{~h}$. Glucose in concentrations of 3 and $9 \mathrm{mg}$ per $100 \mathrm{ml}$ neither diminished fructose metabolism nor did it alter its stimulation by $1000 \mu \mathrm{U}$ of insulin per ml. As the glucose concentration in the medium was further raised, fructose metabolism progressively decreased and insulin accentuated its inhibition. The glucose metabolism increased as the glucose concentration was elevated. At $800 \mathrm{mg}$ of glucose per $100 \mathrm{ml}, 6$ umoles of glucose$\mathrm{U}{ }^{14} \mathrm{C}$ was metabolized per $\mathrm{g}$ per $\mathrm{h}$ and an insulin effect was no longer detectable.

b) Inhibition of glucose transport by phlorizin dihydrate during prolonged incubation. The effects of phlorizin on the metabolism of glucose-U. ${ }^{14} \mathrm{C}$ were investigated in the presence and absence of insulin after different periods of preincubation (Table 1). The 
results were statistically evaluated by the analysis of variance $[11,44,12]$ (Table 2). The difference between basal and phlorizin-inhibited gluoose metabolism $(\Delta)$ increased during preïncubation. The difference was statistically significant between periods I and II and may have been accidental between periods II and III. Phlorizin inhibited the glucose metabolism of tissue in the presence of insulin more markedly after preincubation than before preïncubation. preincubation with actinomycin $\mathrm{D}$ or cycloheximide (Table 3). Actinomycin did not influence the preincubation effect on basal glucose metabolism. In the presence of insulin, actinomyein $\mathrm{D}$ slightly stimulated glucose metabolism. Cycloheximide in a concentration of $3.6 \times 10^{-5} \mathrm{M}$ led to a constant and highly significant inhibition of glucose metabolism to $51 \%$ of the control values. This effect of cycloheximide was prevented by insulin.

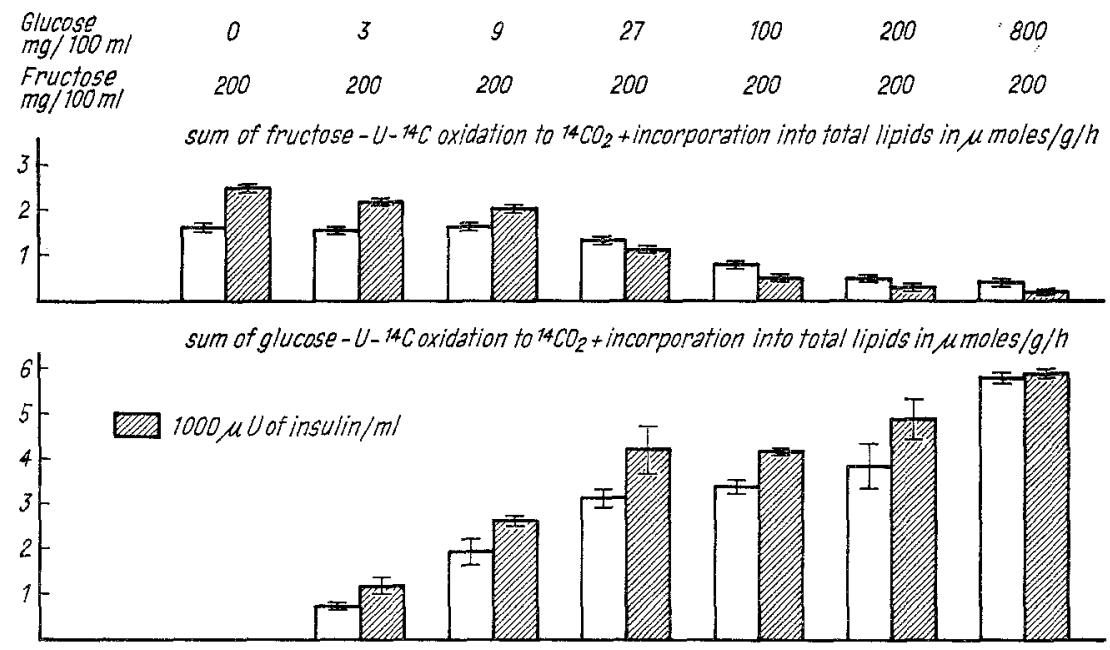

Fig. 1. Effect of various glucose concentrations and of insulin on glucose$\mathrm{U}^{14} \mathrm{C}$ and fructose- ${ }^{-14} \mathrm{C}$ metabolism of adipose tissue of alloxan-diabetic rats after $16 \mathrm{~h}$ of preincubation

Epididymal fat pads of 52 alloxan-diabetic rats were preincubated in four consecutive experiments during $16 \mathrm{~h}$ with $200 \mathrm{mg}$ per $100 \mathrm{ml}$. Afterwards they were pooled and incubated for $2 \mathrm{~h}$ in the presence and absence of $1000 \mu \mathrm{U}$ insulin per ml and with hexose concentrations as indicated. The columns give the means of the results of two flasks with their range

Table 1. Inhibition of glucose- $U-{ }^{14} \mathrm{C}$ oxidation to $\mathrm{CO}_{2}$ and of its incorporation into total lipids by phlorizin dihydrate after different periods of preïncubation

Epididymal adipose tissue of 24 alloxan-diabetic rats was preincubated for 4,8 and $12 \mathrm{~h}$ respectively. Subsequently the tissue was pooled, and its metabolic activity was tested in a $2-\mathrm{h}$ incubation. No insulin was present in the preïncubation medium. The glucose oncentration was $200 \mathrm{mg}$ per $100 \mathrm{ml}$ throughout. The results, which give the means of 4 flasks with the standard errors of the mean, are expressed as umoles of glucose-carbon incorporated into $\mathrm{CO}_{2}$ and total lipids per g per $\mathrm{h}$

\begin{tabular}{|c|c|c|c|c|c|c|c|}
\hline \multicolumn{2}{|c|}{$\begin{array}{l}\text { Additions to } \\
\text { medium, } \\
\text { Final incubation }\end{array}$} & - & $\begin{array}{l}\text { Phlorizin } \\
10 \mathrm{mM}\end{array}$ & $\Delta^{1}$ & $\begin{array}{l}\text { Insulin } \\
1000 \mu \mathrm{U} / \mathrm{ml}\end{array}$ & $\begin{array}{l}\text { Insulin } 1000 \\
\mu \mathrm{U} / \mathrm{ml}, \mathrm{Phlo}- \\
\mathrm{rizin} 10 \mathrm{mM}\end{array}$ & $\Delta_{\text {Ins. }}{ }^{1}$ \\
\hline $\begin{array}{l}\text { Pre } \\
\text { tim }\end{array}$ & $\begin{array}{l}\text { tion } \\
\text { s }\end{array}$ & \multicolumn{6}{|c|}{$\mu$ moles of glucose-U- ${ }^{14} \mathrm{C}$ to $\mathrm{CO}_{2}$ and total lipids per $\mathrm{g}$ per $\mathrm{h}$} \\
\hline$I$ & 4 & $2.51 \pm 0.14$ & $0.72 \pm 0.08$ & 1.79 & $4.07 \pm 0.12$ & $1.94 \pm 0.10$ & 2.13 \\
\hline II & 8 & $3.92 \pm 0.18$ & $1.19 \pm 0.16$ & 2.73 & $6.89 \pm 0.22$ & $2.59 \pm 0.05$ & 4.30 \\
\hline III & 12 & $4.47 \pm 0.08$ & $1.56 \pm 0.10$ & 2.91 & $6.55 \pm 0.51$ & $2.43 \pm 0.43$ & 4.12 \\
\hline
\end{tabular}

1 difference between values of basal and of phlorizin inhibited glucose "uptake".

c) Effect of actinomycin $D$ and of cycloheximide on the stimulation of glucose metabolism during prolonged incubation. Oxidation of glucose- $\mathrm{U}^{14} \mathrm{C}$ to $\mathrm{CO}_{2}$ and its incorporation into total lipids were measured after a d) Metabolic fate of glucose- $U \cdot{ }^{14} C$, glycogen metabolism and lipolysis before and after prolonged incubation. Incorporation of glucose-U. ${ }^{14} \mathrm{C}$ into $\mathrm{CO}_{2}$, total lipids and glycogen, and the response of the tissue to insulin 
were studied before and after a preïncubation of $16 \mathrm{~h}$ (Table 4). Under basal conditions initial glucose metabolism of the diabetic adipose tissue was 1.74 umoles per $g$ per $\mathrm{h}$ (Table 4 , line 1) compared with a mean of 3.83 umoles per $g$ per $h$ in tissue of normal rats under similar conditions. $1000 \mu \mathrm{U}$ of insulin per ml stimulated the glucose metabolism of the diabetic tissue 4-fold. After preincubation without insulin the basal glucose metabolism rose to normal levels but the tissue did not become more sensitive to insulin. Insulin $(250 \mu \mathrm{U}$ per $\mathrm{ml}$ ) in the preincubation medium did not seem to influence the basal glucose uptake during the final incubation, but it increased the insulin sensitivity of the

Table 2. Analysis of variance and variance ratio test of the results presented in Table 1 . Variance ratio $=F$

\begin{tabular}{|c|c|c|c|}
\hline Source of variation & $\begin{array}{l}\text { Degrees } \\
\text { of freedom }\end{array}$ & $\begin{array}{l}\text { Mean Squ } \\
\text { - Insulin }\end{array}$ & $\begin{array}{l}\operatorname{are} \\
+ \text { Insulin }\end{array}$ \\
\hline $\begin{array}{l}\text { P Preïncubation } \\
\text { periods }\end{array}$ & 2 & 4.102 & 7.042 \\
\hline $\begin{array}{l}\text { A Agent (control, } \\
\text { phlorizin) }\end{array}$ & 1 & 36.852 & 74.132 \\
\hline Interaction P. A & 2 & $0.717^{1}$ & $2.927^{3}$ \\
\hline $\begin{array}{l}\mathrm{P} \cdot \mathrm{A}, \text { Periods I } \\
\text { versus II and III }\end{array}$ & 1 & $1.401^{2}$ & $5.817^{4}$ \\
\hline $\begin{array}{c}\mathrm{P} \cdot \mathrm{A}, \text { Periods II } \\
\text { versus III }\end{array}$ & 1 & 0.032 & 0.037 \\
\hline Error & 18 & 0.067 & 0.343 \\
\hline
\end{tabular}

$1 \mathrm{~F}_{1} 0.717 / 0.067 \mathrm{pF}_{1}<0.001$.

${ }^{2} \mathrm{~F}_{2} 1.401 / 0.067 \mathrm{pF}_{2}<0.001$.

${ }_{3} \mathrm{~F}_{1}$ (insulin) $2.927 / 0.343 \mathrm{pF}_{1}$ (ins.) $<0.01$.

${ }_{4} \mathrm{~F}_{2}$ (insulin) $5.817 / 0.343 \mathrm{pF}_{2}$ (ins.) $<0.001$. resulted in an increase of glucose incorporation into fatty acids to $9 \%$ of total glucose metabolism (line 3 ). Insulin in the final incubation stimulated fatty acid synthesis of preïncubated tissue 3 -fold, i.e. to $17 \%$ of

Table 3. Effect of actinomycin $D$ and of cycloheximide during prolonged incubation on glucose metabolism of adipose tissue of alloxan-diabetic rats during final incubation

The preincubation lasted $16 \mathrm{~h}$, the final incubation $2 \mathrm{~h}$. The glucose concentration was $200 \mathrm{mg}$ per $100 \mathrm{ml}$ throughout. The medium for the final incubation did not contain cycloheximide or actinomycin $\mathrm{D}$, whereas the insulin concentration was the same as that indicated for the preincubation medium. The results of the control incubation ( + insulin) were set as $100 \%$. Students t-test was used for statistical analysis

\begin{tabular}{|c|c|c|}
\hline $\begin{array}{l}\text { Additions to } \\
\text { preincubation medium }\end{array}$ & $\begin{array}{l}\text { Sum of glucose-U-14C } \\
\text { to } \mathrm{CO}_{2}+\text { total lipids } \\
\text { in } \% \text { of control 士 SEM } \\
(\mathrm{n})\end{array}$ & $\begin{array}{l}p \\
\text { versus } \\
\text { control }\end{array}$ \\
\hline No addition (control) & 100 & - \\
\hline $\begin{array}{l}\text { Cycloheximide } 3.6 \times \\
10^{-5} \mathrm{M}\end{array}$ & $51.05 \pm 3.56(9)$ & $<0.0005$ \\
\hline $\begin{array}{l}\text { Actinomycin D } 5 \times \\
10^{-5} \mathrm{M}\end{array}$ & $102.80 \pm 5.85(7)$ & $>0.35$ \\
\hline $\begin{array}{l}\text { Insulin } 1000 \mu \mathrm{U} / \mathrm{ml} \\
\text { (control) }\end{array}$ & 100 & - \\
\hline $\begin{array}{l}\text { Cycloheximide } 3.6 \times \\
10^{-5} \mathrm{M} \text { - Insulin } \\
1000 \mu \mathrm{U} / \mathrm{ml}\end{array}$ & $102.83 \pm 4.95(9)$ & $>0.30$ \\
\hline $\begin{array}{l}\text { Actinomycin D } 5 \times \\
10^{-6} \mathrm{M}+\mathrm{Insulin} \\
1000 \mu \mathrm{U} / \mathrm{ml}\end{array}$ & $118.33 \pm 6.19(7)$ & $<0.025$ \\
\hline
\end{tabular}

Table 4. Comparison of glucose-U-14C metabolism before and after prolonged incubation of epididymal adipose tissue of alloxan-diabetic rats, with and without insulin

Initial incubation: Fat pads of 6 alloxan-diabetic rats were pooled immediately after their removal, and incubated for three hours in the presence of $200 \mathrm{mg}$ of uniformly labelled glucose-U-14C per $100 \mathrm{ml}$ with and without $1000 \mu \mathrm{U}$ of insulin per ml. - Final incubation: Fat pads of 12 alloxan-diabetic rats were preïncubated for $16 \mathrm{~h}$ in the absence of any labelled substrate with $200 \mathrm{mg}$ of glucose per $100 \mathrm{ml}$, without and with $250 \mu \mathrm{U}$ of insulin per ml. At the end of the preincubation these tissues were washed and pooled, and incubated for three hours in the same medium as used for the initial incubation. - The results give the means of triplicate determinations \pm SEM

\begin{tabular}{|c|c|c|c|c|c|c|c|c|c|}
\hline \multirow{4}{*}{ : } & & \multirow{2}{*}{$\begin{array}{l}\text { Insulin } \\
1000 \\
\mu \mathrm{U} / \mathrm{ml}\end{array}$} & \multicolumn{7}{|c|}{ Incorporation of glucose ${ }^{-}{ }^{14} \mathrm{C}$ in $\mu$ moles $/ g / h$ into } \\
\hline & & & $\mathrm{CO}_{2}$ & Total lipids & Fatty acids & $\begin{array}{l}\text { Glyceride- } \\
\text { glycerol }\end{array}$ & Glycogen & $\begin{array}{l}\text { Total }\left(\mathrm{CO}_{2}+\right. \\
\mathrm{TL}+\text { Glycoge }\end{array}$ & \\
\hline & no & - & $0.90 \pm 0.06$ & $0.66 \pm 0.04$ & $0.06 \pm 0.01$ & $0.60 \pm 0.04$ & $0.18 \pm 0.02$ & $1.74 \pm 0.10$ & 1 \\
\hline & preïncubation & + & $3.39 \pm 0.13$ & $2.17 \pm 0.15$ & $1.24 \pm 0.03$ & $0.93 \pm 0.12$ & $2.05 \pm 0.09$ & $7.61 \pm 0.28$ & 2 \\
\hline \multirow{4}{*}{ 氶 } & preïneubation & - & $2.82 \pm 0.03$ & $3.13 \pm 0.06$ & $0.55 \pm 0.01$ & $2.58 \pm 0.06$ & $0.29 \pm 0.01$ & $6.23 \pm 0.09$ & 3 \\
\hline & without insulin & + & $4.08 \pm 0.05$ & $4.15 \pm 0.15$ & $1.64 \pm 0.13$ & $2.51 \pm 0.12$ & $1.45 \pm 0.09$ & $9.68 \pm 0.24$ & 4 \\
\hline & preïncubation & - & $3.65 \pm 0.21$ & $3.08 \pm 0.27$ & $0.95 \pm 0.19$ & $2.13 \pm 0.11$ & $0.10 \pm 0.02$ & $6.83 \pm 0.49$ & 5 \\
\hline & with insulin & + & $6.38 \pm 0.18$ & $7.01 \pm 0.38$ & $4.59 \pm 0.23$ & $2.42 \pm 0.29$ & $0.32 \pm 0.06$ & $13.71 \pm 0.43$ & 6 \\
\hline
\end{tabular}

tissue. Fatty acid synthesis from glucose- $\mathrm{U}_{-}{ }^{14} \mathrm{C}$ in diabetic adipose tissue initially amounted to $3.4 \%$ of the sum of glucose incorporation into $\mathrm{CO}_{2}$, total lipids and glycogen. It was stimulated 20 -fold by insulin (Table 4, line 1 and 2). Preincubation of the tissue the total glucose metabolism. When the preincubation medium contained insulin, fatty acid synthesis rose to $14 \%$, and was further enhanced to $33 \%$ when insulin was also present during the final incubation.

Incorporation of glucose-U. ${ }^{14} \mathrm{C}$ into glyceride-gly- 
cerol during the initial incubation was slightly increased by insulin. Preïncubation led to a more marked increase, and insulin in the final incubation medium was without effect.

The glycogen content of adipose tissue of alloxandiabetic rats was too small to be measured accurately. After $16 \mathrm{~h}$ of preincubation without insulin the glycogen content was approximately 2 umoles of glucose per $g$ of tissue. Insulin in the initial and final incubation had practically no effect on glycogen content (Fig. 2). When the tissue was in contact with insulin throughout the entire period of incubation (initial and final) the glycogen content was increased.

Insulin stimulated glucose incorporation into glycogen during the initial incubation approximately 10-fold (Table 4). Sixteen hours of preïncubation resulted in a slight increase of basal incorporation into glycogen, which was stimulated 5 -fold by insulin, while the glycogen content of the tissue was unchanged (Fig. 2). Preincubation of adipose tissue with insulin resulted in a decrease of basal glucose incorporation into glycogen, and the effect of insulin in the final incubation was small.

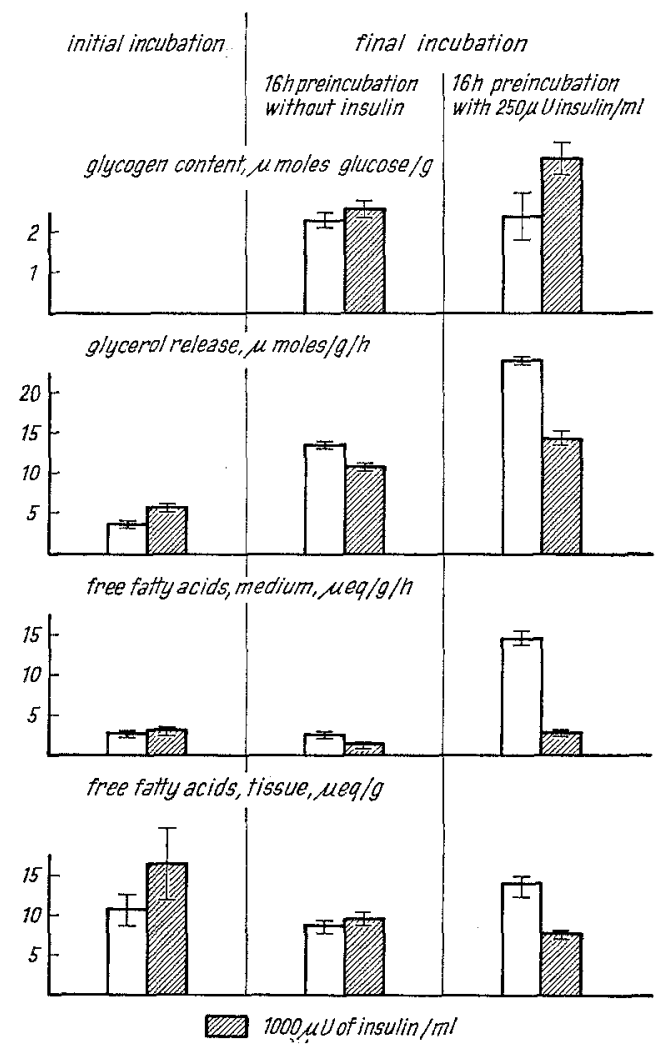

Fig. 2. Comparison of the glycogen content, glycerol and free fatty acid release and of the free fatty acid content of adipose tissue of alloxan-diabetic rats before (initial) and after (final) prolonged incubation

Results from the same experiment as in Table 4. The results give the mean and SEM of three flasks. For incubation conditions see legend to Table 4
Glycerol release per $g$ of adipose tissue of diabetic rats (Fig. 2, initial) was increased above that of normal rats. Insulin enhanced the glycerol release in diabetic tissue but not in normal tissue. Preincubation resulted in an increase of basal glycerol release, which was markedly inhibited by insulin. This effect of insulin was more pronounced in tissue that had been preincubated with insulin.

Glucose uptake was correlated with fatty acid synthesis over a wide range of glucose uptake under various conditions that influence the glucose uptake (insulin, hexose concentration, preïncubation with and without insulin). The results of a representative experiment are shown in Fig. 3. The arbitrarily drawn curve in Figure 3 indicates that the tissues which were in contact with insulin incorporated relatively more glucose- $\mathrm{U}^{14} \mathrm{C}$ into fatty acids than those incubated without insulin at corresponding levels of glucose uptake.

\section{Discussion}

Many of the effects of insulin on adipose tissue metabolism may result from accelerated glucose entry into the cells by way of facilitated glucose diffusion (for review see RENoLd et al. [43]). However, insulin affects glycerol and free fatty acid release [20], protein

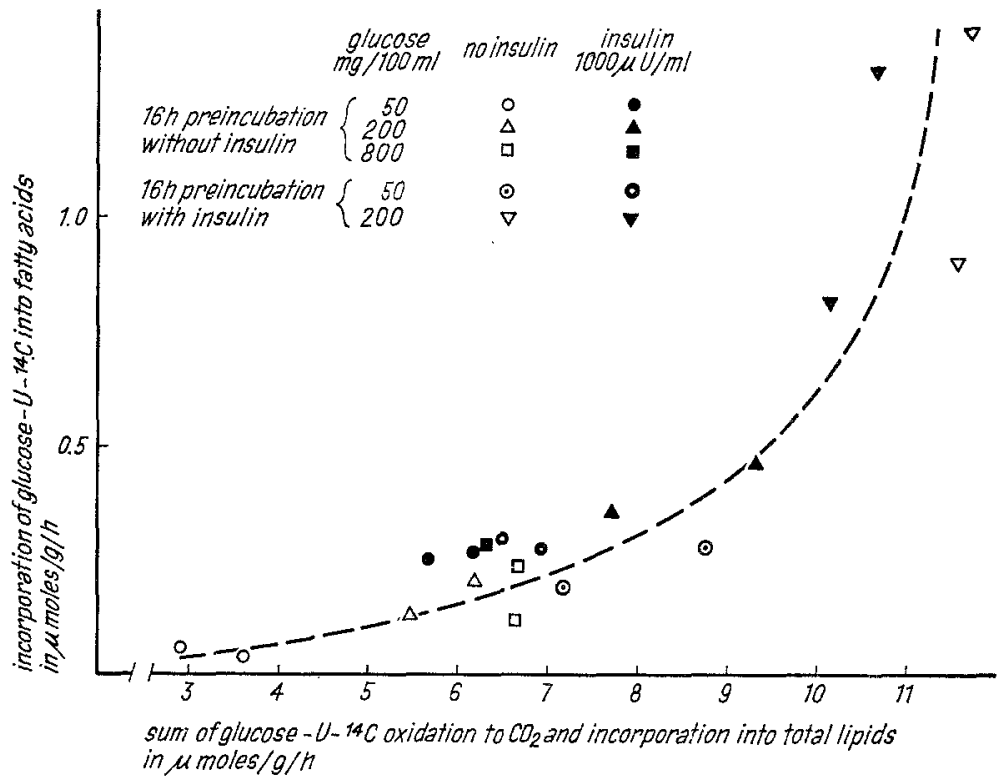

Fig. 3. Glucose-U-14 $\mathrm{C}$ incorporation into fatty acids as a function of glucose "uptake" by adipose tissue of alloxan-diabetic rats after $16 \mathrm{~h}$ of preïncubation

Epididymal adipose tissue of 20 alloxan-diabetic rats was incubated in the presence and absence of $250 \mu \mathrm{U}$ of insulin per ml, and with $200 \mathrm{mg}$ of glucose per $100 \mathrm{ml}$. At the end of the preincubation these tissues were washed, pooled and incubated for 2 hours with uniformly labelled glucose ${ }^{14} \mathrm{C}$ in concentrations of 50,200 and 800 $\mathrm{mg}$ per $100 \mathrm{ml}$ in the presence and absence of $1000 \mathrm{uU}$ of insulin per $\mathrm{ml}$. Each dot represent the results of one flask 
metabolism $[30,3,26]$ and the resting electrical membrane potential in the absence of glucose [1], so that not all effects of insulin can be explained by its action on glucose transport.

Diabetic adipose tissue has a markedly diminished glucose metabolism, which can be restored to normal by insulin therapy in vivo (for review see WINEGRAD et al. [46]). Metabolic abnormalities similar to those found in diabetic adipose tissue also occur when cellular carbohydrate starvation is due to fasting. These are normalized by refeeding. Whether insulin reverses the diabetic abnormalities only by relieving cellular carbohydrate starvation, or whether other effects of the hormone are essential cannot be decided, since it is rarely possible to obtain reproducible rates of glucose uptake under physiological conditions by means other than by insulin. Stimulation of glucose metabolism of rat adipose tissue in vitro without insulin has been achieved by hyperosmolarity of the medium [34] and by increasing the hexose concentrations [32].

Severe derangements of adipose tissue metabolism of alloxan-diabetic rats were observed when no insulin was given for at least $48 \mathrm{~h}[45,16]$. For the restoration of these "diabetic" abnormalities of adipose tissue metabolism 12 or more hours of insulin treatment in vivo was required $[46,28]$. In a preceeding paper we have described a method for the prolonged incubation of adipose tissue in vitro [37]. The diminished glucose uptake of the tissue of alloxan-diabetic rats was normalized within 8 to $16 \mathrm{~h}$ of incubation in the absence of insulin. The same experimental model was used to study whether or not the normalization of glucose uptake during prolonged incubation in vitro without insulin may also lead to a reversal of other diabetic alterations of adipose tissue metabolism.

An important difference between normal adipose tissue and diabetic adipose tissue after "normalization" by prolonged incubation became apparent when the fructose metabolism was investigated. Fructose is transported into the adipose cell by a separate transport system for which glucose does not compete. Apparently, fructose is phosphorylated by the same adipose tissue hexokinase as glucose. The affinity of this phosphorylating enzyme is much greater for glucose than for fructose $[18,29,6,24]$. The lack of competition at the hexokinase level between these two hexoses in tissue of normal fed rats at physiological glucose concentrations is due to the virtually complete absence of free (non-phosphorylated) glucose within the cell. When maximal rates of glucose uptake are induced by high glucose concentrations (810 $\mathrm{mg}$ of glucose per $100 \mathrm{ml}$ ) and insulin stimulation $(1000 \mu \mathrm{U}$ per $\mathrm{ml})$, the fructose metabolism of adipose tissue is depressed [18]. In tissues of alloxan-diabetic rats the suppression of fructose phosphorylation becomes significant at much lower rates of glucose uptake [16]. After $16 \mathrm{~h}$ of incubation, phosphorylation became already limiting at glucose concentrations between 30 and $100 \mathrm{mg}$ per 100 $\mathrm{ml}$ (Fig. 1), i.e. when the glucose uptake corresponded to that of nonstimulated normal tissue. It seems likely that the activity of the phosphorylating system known to be depressed in diabetic tissue $[36,2]$ did not increase in proportion to the glucose uptake during the incubation period so that phosphorylation rather than transport became rate limiting for glucose metabolism. Therefore, an accurate estimation of glucose transport rates can not be derived from results of glucose-U ${ }^{14} \mathrm{C}$ metabolism. Nevertheless, it is quite clear that insulin stimulated glucose transport of preincubated tissue to a relatively small extent, even at low glucose concentrations (3 and $9 \mathrm{mg}$ per $100 \mathrm{ml}$ ) which did not inhibit fructose metabolism (Fig. 1).

Intact membranes are prerequisites for the effect of insulin on sugar transport. Prolonged incubation in vitro might well damage the plasma membrane so that glucose might freely diffuse into the cell. 'Therefore, we felt obliged to characterize hexose transport. The data reported in Tables 1 and 2 indicate that phlorizin, a selective inhibitor of carrier-mediated glucose transport $[35,5,15]$ significantly inhibited the preincubation effect on ghucose metabolism. It is concluded that prolonged incubation in vitro stimulated facilitated diffusion. The same conclusion was reached by Fessler, Rubinstern and Beck [10] using space measurement of 3-0-methylglucose in adipose tissue of fed and fasted rats. The stimulation of glucose transport by insulin after prolonged incubation was also inhibited by phlorizin. The intimate mechanism of the stimulation of glucose transport by prolonged incubation is as yet unknown. It is conceivable that the swelling of the extracellular space during incubations in vitro $[37,25,4]$ may lead to structural and functional changes of the membranes. The glucose carrier in free adipose tissue cells is saturated at relatively low glucose concentrations. This may be due to an increased accessibility of transport sites for glucose. Glucose transport in muscle is stimulated by anoxia, muscular work and by some inhibitors of glycolysis $[41,40,39]$. These effects are also inhibited by phlorizin, which indicates that stimulation of facilitated diffusion can result from changes of energy metabolism.

One of the glucose-independent effects of insulin is the inhibition of lipolysis. In the presence of glucose, insulin reduces reësterification of fatty acids despite the simultaneous stimulation of glucose uptake [20]. In contrast, the stimulation of glucose metabolism by prolonged incubation was accompanied by a 4-fold rise of glycerol release (4), (Fig. 3), and a corresponding: increase of glucose-U- ${ }^{14} \mathrm{C}$ incorporation into glycerideglycerol (Table 4, line 3 ). The amount of free fatty acids in the medium and tissue was approximately the same before and after prolonged incubation.

Net glycogen synthesis seemed to occur during prolonged incubations in the absence of insulin (Fig. 2). Insulin stimulated the incorporation of glucose-U- ${ }^{14} \mathrm{C}$ into glycogen about 10-fold during the initial incubation, and 5 -fold after preincubation without insulin. When insulin was present throughout the entire incu- 
bation period, incorporation of glucose into glycogen was decreased while glycogen content was higher than under any other conditions of incubation. This is best explained by an inhibitory action of insulin on phosphorylase. These results are compatible with those obtained in fasted-refed rats, which indicate that phosphorylase activity and the availability of glucose-6phosphate regulate the glycogen content of adipose tissue $[14,19]$. A stimulation of glycogen-synthetase activity by insulin as reported by JUNGAS [33] was not demonstrable in these experiments. The glycogen content of "diabetic" adipose tissue after prolonged incubation was small compared with the marked accumulation of glycogen in adipose tissue of fastedrefed rats in vivo.

Impaired glucose utilization finally leads to depressed lipogenesis in adipose tissue of alloxan-diabetic rats. Insulin administered in vivo normalizes the glucose incorporation into fatty acids within 12 or more hours $[46,28]$. The incorporation of glucosecarbon into fatty acids was raised by prolonged incubation in vitro, but it remained below normal, even when insulin was present during preïncubation and final incubation. The highest value of fatty acid synthesis from glucose- $\mathrm{U}_{-}{ }^{14} \mathrm{C}$ was $33 \%$ of the total glucose metabolism (Table 4, line 6). A correlation between fatty acid synthesis and glucose metabolism over a large range is shown in Figure 3. At comparable rates of glucose metabolism, fatty acid synthesis from glucose-U- ${ }^{14} \mathrm{C}$ was somewhat higher with insulin than without insulin. Unfortunately, this effect of insulin on lipogenesis could not be evaluated in a statistically meaningful way. It would be of interest to measure the activity of the enzyme system which is responsible for the desaturation of stearic to oleic acid. Its activity is reduced in adipose tissue of diabetic animals, reflecting the decreased rate of total lipid biosynthesis [22].

The normalization of the metabolic defects of adipose tissue metabolism by insulin in vivo involves $d e$ novo synthesis of enzymes, in particular hexolinase [2] and stearate-desaturating enzyme [22, 23]. Actinomycin D did not inhibit the effect of prolonged incubation in vitro on glucose metabolism (Table 3 ) indicating that RNA-synthesis was not involved [42]. On the other hand, the preincubation effect was consistently decreased by cycloheximide (Table 3), which would be compatible with the hypothesis that protein synthesis may be of some importance in the preincubation effect $[8,9]$. It is most puzzling that insulin abolished the inhibitory effect of cycloheximide, particularly in view of the recent report of WooL and CAVICOHI, [47] who demonstrated an effect of insulin on protein synthesis in muscle ribosomes.

\section{References}

1. Bhigelmai, P.M., and P.B. Hollander: Effect of insulin upon resting electrical potential of adipose tissue. Proc. Soc. exp. Biol., N.Y. 110, 590-595 (1962).
2. Borrebatr, B.: Increase in epididymal adipose tissue hexolkinase activity induced by glucose and insulin. Biochim. biophys. Acta 128, $211-213$ (1966).

3. Carruthers, B.M., and A.I. Winegrad : Effects of insulin on amino acid and ribonucleic acid metabolism in rat adipose tissue. Amer. J. Physiol. 202, $605-610(1962)$.

4. Crofford, O.B., and A.E. Renold : Glucose uptake by incubated rat epididymal adipose tissue: rate limiting steps and site of insulin action. J. biol. Chem. 240, 14-21 (1965).

5. - - Glucose uptake by incubated rat epididymal adipose tissue: Characteristics of the glucose transport system and action of insulin. J. biol. Chem. 240, 3237-3244 (1965).

6. Di Pietro, D.L.: Hexokinase of white adipose tissue. Biochim. biophys. Acta 67, 305-312 (1963).

7. EARLe, W.R.: Production of malignancy in vitro; mouse fibroblast cultures and changes seen in living cells. J. nat. Cancer Inst. 4, 165-212 (1943).

8. EnNIS, H. L., and M. LUBIN: Cycloheximide: Aspects of inhibition of protein synthesis in mammalian cells. Science 146, 1474-1476 (1964).

9. Feliowtit, L., B. Colombo, and G. Bagliont: Inhibition of protein synthesis in reticulocytes by antibiotics. II. The site of action of cycloheximide, streptovitacin A and pactamycin. Biochim. biophys. Acta 119, 120-129 (1966).

10. Fessuer, A., D. Rubinstein, and J.C. Beck: The effect of prolonged incubation on lipid synthesis by rat adipose tissue. J. biol. Chem. 242, 1462-1465 (1967).

11. FISHER, R.A.: International Mathematical Conference. Toronto: 1924.

12. - , and F. YATES: Statistical Tables. Edinburgh: Oliver and Boyd 1938-1953.

13. Folch, J., M. LeEs, and G.H. Sloane Stanley: A simple method for the isolation and purification of total lipids from animal tissues. J. biol. Chem. 226, $497-509$ (1957).

14. Frerichs, H., and E.G. Bald: Studies on the metabolism of adipose tissue. XI. Activation of phosphorylase by agents which stimulate lipolysis. Biochemistry 1, 501-509 (1962).

15. - - Studies on the metabolism of adipose tissue. XVI. Inhibition by phlorizin and phloretin of the insulin-stimulated uptake of glucose. Biochemistry 3, $981-985$ (1964).

16. Froesch, E.R.: Fructose metabolism in adipose tissue from normal and diabetic rats. In: RENoLD, A.E., and G.F. CAHILI, JR., Eds., Handbook of Physiology, Section 5, Adipose Tissue, p. 281. Washington, D.C.: American Physiological Society 1965.

17. Froesch, E.R., H. Bürgi, E.B. Ramseier, P. BaI$L Y$, and A. LABHART: Antibody-suppressible and nonsuppressible insulin-like activities in human serum and their physiologic significance. An insulin assay with adipose tissue of increased precision and specificity. J. clin. Invest. 42, 1816-1834 (1963).

18. - , and J. Ginsberg: Fructose metabolism of adipose tissue. I. Comparison of fructose and glucose metabolism in epididymal adipose tissue of normal rats. J. biol. Chem. 237, 3317-3324 (1962).

19. - M. WaLd vogEL, U.A. MeYeR, A. JAKob, and A. LABHART: Effects of 5-methylpyrazole-3-carboxylic acid on adipose tissue. I. Inhibition on lipolysis, effects on glucose-, fructose-, and glycogen-metabolism in vitro and comparison with insulin. Mol. Pharmacol., 3, 429-441 (1967).

20. - H. BÜRGr, P. BALLY, and A. LABHART: Insulin inhibition of spontaneous adipose tissue lipolysis and effects upon fructose and glucose metabolism. Mol. Pharmacol. 1, 280-296 (1965). 
21. Garton, D.J., and J.N. FarN: Effects of prolonged incubation of isolated fat cells on their response to hormones stimulating lipolysis and glucose metabolism. Biochem. J. 98, 557-561 (1966).

22. GELLHORN, A., and W. BENJAMIN : The intracellular localization of an enzymatic defect of lipid metabolism in diabetic rats. Biochim. biophys. Acta 84, $167-175(1964)$

23. - - The effect of insulin on mono-unsaturated fatty acid synthesis in diabetic rats. The stability of the informational RNA and of the enzyme system concerned with fatty acid desaturation. Biochim. biophys. Acta 116, 460-466 (1966).

24. Ginsberg, J.L.: Fructosestoffwechsel des Fettgewebes. II. Abbauwege der Fructose im epididymalen Fettgewebe der Ratte. Z. ges. exp. Med. 139, $101-$ $111(1965)$.

25. Goodman, H.M.: Effects of insulin on water uptake by adipose tissue during incubation in vitro. Endocrinology 76, 531 (1965).

26. - Stimulatory action of insulin on leucine uptake and metabolism in adipose tissue. Amer. J. Physiol. 206, 129-132 (1964).

27. GoRDor, R.S., Jr.: Unesterified fatty acids in human blood plasma. II. The transport function of unesterified fatty acids. J. clin. Invest. 36, 810-815 (1957).

28. Hausberger, F.X., S. W. Mitstein, and R.J. RutMax: The influence of insulin on glucose utilization in adipose and hepatic tissues in vitro. J. biol. Chem. 208, $431-438$ (1954)

29. Hernandez, A., and A. Sols: Transport and phosphorylation of sugars in adipose tissue. Biochem. J. $86,166-172(1963)$.

30. Herrera, M.G., and A.E. Rerold: Hormonal offects of glycine metabolism in rat epididymal adipose tissue. Biochim. biophys. Acta 44, $165167 \cdot(1960)$.

31. - G.R. PhrrIPPS, and A.E, Renold : Stimulation of metabolic activity of adipose tissue from fasted rats by prolonged incubation in vitro. I. Requirement for glucose and insulin. Biochim. biophys. Acta 106, $221-233(1965)$

32. Jeanrenaud, B, and A.E. Renold: Studies on rat adipose tissue in vitro: IV. Metabolic patterns produced in rat adipose tissue by varying insulin and glucose concentrations independently from each other. J. biol. Chem. 234, 3082-3087 (1959).

33. Jungas, R.L.: Role of cyclic-3', 5'-AMP in the response of adipose tissue to insulin. Proc. nat. Acad. Sci., Wash. 56, 757-763 (1966).

34. Kuzuya T., E. Samous, and R.H. Wminams: Stimulation by hyperosmolarity of glucose metabolism in rat adipose tissue and diaphragm in vitro. J. biol. Chem. 240, 2277-2283 (1965).

35. Lotspeich, W.D.: Phlorizin and the cellular transport of glucose. Harvey Lect. 56, 63-91 (1960-61).
36. Mo Lean, P., J. Brown, K. Gremnslade, and K. BREw: Effect of alloxan-diabetes on the glucose-ATP phosphotransferase activity of adipose tissue. Biochem. Biophys, Res. Comm. 23, 117-121 (1966).

37. Merer, U.A.: Stoffwechsel des Fettgewebes normaler, alloxan-diabetischer und nach Nahrungskarenz wiedergefiutterter Ratten während langfristiger Inkubation in vitro. Diabetologia 2, 189-194 (1966).

38. - , and E.R. Froesch: Partial normalization of "diabetic" adipose tissue metabolism in vitro without insulin (Abstract). Diabetologia 2, 211 (1966).

39. Morgan, H.E., D.M. REger, and C.R. Park: Identification of a mobile carrier mediated sugar transport system in muscle. J. biol. Chem. 239, 369-374 (1964).

40. - J.R. Neely, and J.P. Brineaux, In: Chatee, B., R.W. Estabrook, and J.R. Wiltitamson, Eds., Colloquium of the Johnson Research Foundation: Control of energy metabolism, p. 347. New York - London: Academic Press 1965.

41. Randle, P.J., and G.H. Smrth: Regulation of glucose uptake by muscle. I. The effect of insulin, anaerobiosis and cell poisons on the uptake of glucose and release of potassium by isolated rat diaphragm. II. The effects of insulin, anaerobiosis and cell poisons on the penetration of isolated rat diaphragm by sugars. Biochem. J. 70, 490-500 (1958).

42. Reich, E., and I.H. Goldberk, In: J.N. DAvidson and W.E. CoHs Eds., Progress in nucleic acid research and molecular biology, vol. 3, p. 183. New York: Academic Press, Ine. 1964.

43. Renold, A.E., O.B. Crofford, W. Stauffacher, and B. Jeanrenaud : Hormonal control of adipose tissue metabolism, with special reference to the effects of insulin. Diabetologia 1, 4-12 (1965).

44. SNEDECOR, G. W.: Analysis of variance and covariance. Iowa: State University Press, Iowa 1934.

45. Tarrant, M. E., and J. Asmmore : Sequential changes in adipose tissue metabolism in alloxan-diabetic rats. Diabetes 14, 179-185 (1965).

46. WINeGrad, A.I., Y. Goto, and F.D.W. Lukens, In: RODAHL, K. and B. Issekutz, Eds., Fat as a tissue, p. 344. - 361 New York: Mc Graw-Hill, 1964.

47. Wool, I.G., and Ph. CAvicCHI: Insulin regulation of protein synthesis by muscle ribosomes: Eiffect of the hormone on translation of messenger RNA for a regulatory protein. Proc. nat. Acad. Sci., Wash. 56, $991-998(1966)$.

Dr. E.R. Froesch

Metabolic Unit

Department of Medicine

University of Zürich

Zürich, Switzerland 